\title{
TECHNICAL EFFICIENCY EVALUATION: STUDY ON MALAYSIAN ELECTRICAL AND ELECTRONICS FIRMS
}

\author{
Mohd Fahmy-Abdullah ${ }^{*}$, Lai Wei Sieng², and Hamdan Muhammad Isa ${ }^{3}$ \\ ${ }^{I}$ Faculty of Technology Management and Business, Universiti Tun Hussein Onn \\ Malaysia, 86400 Parit Raja, Batu Pahat, Johor, Malaysia \\ ${ }^{2}$ Faculty of Economic and Management, Universiti Kebangsaan Malaysia, \\ 43600 Bangi, Selangor, Malaysia \\ ${ }^{3}$ Jabatan Perangkaan Malaysia, Blok C6, Kompleks C, Pusat Pentadbiran Kerajaan \\ Persekutuan, 62514 Putrajaya, Malaysia \\ ${ }^{*}$ Corresponding author: mohdfahmy@uthm.edu.my
}

Published online: 30 December 2019

To cite this article: Fahmy-Abdullah, M., Lai, W.S., and Isa, H.M. (2019). Technical efficiency evaluation: Study on Malaysian electrical and electronics firms. Asian Academy of Management Journal, 24(2), 1-19. https://doi.org/10.21315/aamj2019.24.2.1

To link to this article: https://doi.org/10.21315/aamj2019.24.2.1

\begin{abstract}
The purpose of this study is to measure the level of technical efficiency (TE) and to analyse the factors of technical inefficiency of electrical and electronic manufacturing industry in Malaysia in 2015. The determinants studied include capital-labour ratio, education level ratio, firm size, information technology, and communication expenses, training expenditure, wage rates, and research and development expenditure. This study uses data on 531 firms based on the latest census of 2015 obtained from the Department of Statistics, Malaysia using the Stochastic Frontier Analysis (SFA) approach. Based on the results, the firm's overall TE level is high at 0.836. For the determinants of TE, it was found that firm size can reduce the inefficiencies of firm, while capital-labour ratios shows a positive relationship with technical inefficiencies in firms. The policy implication is that the electrical and electronic manufacturing industry needs to focus on scale economic achievement and high technology production in line with the competency level of employee and create more international industry technical cooperation.
\end{abstract}

Keywords: technical efficiency, electric and electronic manufacturing industry, Stochastic Frontier Analysis, manufacturing industry in Malaysia, capital-labour ratio

(C) Asian Academy of Management and Penerbit Universiti Sains Malaysia, 2019. This work is licensed under the terms of the Creative Commons Attribution (CC BY) (http://creativecommons. org/licenses/by/4.0/). 


\section{INTRODUCTION}

Efficiency is the effectiveness in input usage which is influenced by technical production technic, technological innovation, skills management, and employee skills (Fahmy-Abdullah, 2017). Technical efficiency (TE), whereas illustrates the ability of firms to produce the maximum output when given a set of inputs (Farrell, 1957 Fahmy-Abdullah et al., 2018). Porcelli (2009) asserted that the level of TE is equal to one and if the score is less than one, it indicates the technical inefficiency. Study on the determinant of TE is very important in the production theory (FahmyAbdullah et al., 2017). Long-term efficiency can determine the economic growth of a country (Fahmy-Abdullah et al., 2017) and contributes to productivity growth (Fahmy-Abdullah, 2017 Fahmy-Abdullah et al., 2018). The long-term growth of per capita income in the economy must be supported by productivity growth (Solow, 1956). Productivity reflects a more efficient usage of inputs and this will increase the competitiveness of a country (Ismail et al., 2017). Productivity is the most important aspect at every stage of the economic development planning policy in Malaysia, i.e., Rancangan Malaysia Ke-7 (RMKe-7), 1995-2000 to Rancangan Malaysia Ke-11 (RMKe-11), 2015-2020 and is the main policy of economic growth to increase the contribution of the country's gross domestic product (GDP).

Electrical and electronics manufacturing industry is the largest contributor to the country's total exports and is a major contributor for the manufacturing sector for the country's GDP. In 2016, the electrical and electronic manufacturing industry contributed $36.6 \%$ of total country-wide exports, up by RM9.9 billion to RM287.9 billion (Jabatan Perangkaan Malaysia, 2018a). Positive growth performance was recorded in 2017 at $8.0 \%$ (up from 7.2\% in 2016) due to strong external demand (Jabatan Perangkaan Malaysia, 2018b). Therefore, TE in the electrical and electronic manufacturing which is the main industry in manufacturing sector plays an important role in contributing to the growth of national productivity. As an open economy, industries in Malaysia, including electrical and electronics, face global challenges such as global economic slowdown, the ever-changing ringgit and oil prices (MITI, 2016). Annual GDP National Accounts Report (2012) found that the electrical and electronics manufacturing industry experienced a $2.4 \%$ fall from the effects of lower external demand and supply disruptions from Europe, Japan, and Thailand. Despite growth of $8.6 \%$ in 2015, the industry's performance rebounded back in 2016, which was around 7.1\% (Jabatan Perangkaan Malaysia, 2017). In fact, the electrical and electronics manufacturing industry only grew slightly and dropped by $6 \%$ during the first seven months of 2016 compared to 2015 by $7.9 \%$ (MPC, 2017). This situation requires electrical and electronics manufacturing firms to achieve high productivity to address the emergence of new operations, the change in technological, and technological efficiency by increasing 
the efficiency and performance of the industry. This will be able to enhance the country's economic momentum as contained in the National Key Result Areas (NKRAs) to ensure the electrical and electronics manufacturing industry as the driver of the country's transformation. An industry that is not willing to increase the level of TE is undoubtedly unable to increase the economic growth momentum as a result of economic openness and trade liberalisation (Fahmy-Abdullah et al., 2018). The fact that liberalisation has demanded the manufacturing industry's ability to increase the amount of additional output or value added using the existing firm's input to produce optimum output (MPC, 2015).

Based on previous research, studies on the efficiency of the electrical and electronic manufacturing industry in Malaysia are still lacking compared with other industries. Most studies such as Siang et al. (2012), Sulaiman and Rashid (2013), and Jajri and Ismail (2014) only discussed the electrical and electronics manufacturing industry in general. There is also no consideration on the determinants of technical inefficiency such as Mahadevan (2002a; 2002b; 2002c) and Sulaiman (2012). In fact, recent studies such as by Khalifah et al. (2015), and Khalifah and Jaafar (2017) used data at the industry level but not really use cross-sectional data at the firm or micro level. As a result, the level of TE obtained is not significant. Data at the firm level can play an important role in obtaining more precise TE values (Battese \& Coelli, 1995). The TE level can be measured more accurately when data at the firm level and taking into account the inefficiency factors that can improve the improvement effort (Fahmy-Abdullah et al., 2018). Besides that, this microdata is also more efficient compared with the time-series data as the researcher has the advantage of solving some of the problems associated with the estimates and the bias aggregation to aggregated industry data (Md Isa, 2005). Tingley et al. (2005) stressed that estimation by using firm data as individuals is better as further analysis of factors affecting the level of estimation can be assessed. In conclusion, new empirical findings can be generated using data at the firm level taking into account the technical inefficiency factors besides the resulting TE value being more significant and accurate.

Hence, based on the problems and gaps of this study, an effort is made to study the extent of the efficiency and determinants of the inefficiency of the electrical and electronic manufacturing industry in Malaysia using the latest firm-level data sources. This study adopted data from Economic Census 2015 (latest) which is conducted every five years. New findings can be obtained using firm-level data and take into account factors of technical inefficiency (Fahmy-Abdullah et al., 2017). This study is very important to increase TE and determine the factor of technical inefficiency to facing liberalisation challenge and in line with the national target to develop the electrical and electronics manufacturing industry as one of the 
competitive industries not only locally but also internationally based on current performance. In fact, this industry needs to be more productive and competitive to increase productivity levels (MPC, 2015). This can illustrate how far the TE and the technical inefficiencies of electrical and electronic manufacturing industry are in the long run. This study is also able to find out and answer the question of how far the efficiency level is, as well as to determine what factors in the technical inefficiency of the electrical and electronic manufacturing industry in Malaysia.

This study uses data at the firm level in 2015 using the Stochastic Frontier Analysis (SFA) approach involving two analyses. The first analysis will determine the level of technical competence among selected firms. The second analysis is to determine the determinant factors of technical inefficiency of the electrical and electronic manufacturing industry in Malaysia in 2015. The second part of this article discusses relevant past studies, while the third part presents the research methodology, data sources, and model specifications. The fourth part reports the empirical results and the last part provides the conclusion and implications of the study.

\section{LITERATURE REVIEW}

The use of data at the firm level throughout previous studies has been increasingly addressed by researchers. Heterogeneous and biased aggregation problems using industry-level data can be solved using firm-level data (Fahmy-Abdullah et al., 2017). In addition, estimates are more accurate with microdata than time series in the form of aggregate form. There are a number of previous studies involving some industries to estimate TE using firms' data including Le and Harvie (2010), Essmui et al. (2013), and Fahmy-Abdullah et al. (2018). Jarboui et al. (2015) emphasised that TE estimates using firm data as individuals are better as further analysis of factors affecting TE levels can be studied. Value of TE is often obtained using parametric and non-parametric approaches. Data envelopment analysis (DEA) is a non-parametric approach that does not make any assumption about the form of the production function. On the other hand, DEA is a function of best practice empirical production based on input and output observations (Fahmy-Abdullah \& Talib, 2018). Studies such as Sun et al. (2015), Fahmy-Abdullah and Talib (2018), and Fahmy-Abdullah et al. (2019) use the DEA approach as their method of study. However, the DEA model cannot identify the difference between technical inefficiency and random error (Coelli et al., 2005; Fahmy-Abdullah, 2017). This study applied the parametric approach, the SFA model to measure TE and determinants of technical inefficiency. The SFA approach gives more advantages as it is possible to identify inconsistent data when the analysis is conducted and 
easily adapted to the environmental variables (Coelli et al., 2005; Fahmy-Abdullah et al., 2018). In addition, random shocks which have an impact on production can be identified (Jarboui et al., 2015).

Furthermore, analysis of the structure, the assessment of the determinants, and the firm's performance can be well-analysed with SFA (Cullinane et al., 2006). Tingley et al. (2005) also proved that the level of TE measured by the SFA approach was much better and consistent than the DEA approach based on low variance values. The SFA approach has also been adopted in studies such as Jarboui et al. (2015), Fahmy-Abdullah et al. (2017), and Fahmy-Abdullah et al. (2018). There are also previous studies that not only measure the level of TE but also examine the determinants of a firm or industry. An early study by Katz (1969) emphasised that the capital-labour ratio was one of the major contributors to output growth and productivity. Capital is a source of innovation for firms in the production process (Nelson \& Phelps, 1966). Stevens and Kneller (2003) proved that the capitallabour ratio has a positive relationship with efficiency and productivity. When a firm can capitalise on high capital volumes, the positive impact on efficiency and productivity can be achieved in line with the maximum machine utilisation in the production process (Bertrand, 2013; Fahmy-Abdullah et al., 2018). However, in the event of a capital increase such as technological purchases and at the same time, the skills of the employees are not upgraded, it affects the firm's efficiency level as employees are forced to adapt to new technologies acquired (FahmyAbdullah et al., 2019).

Worker's efficiency can be increased through training for employees. Through training, labour force's skills increase and produce a higher quality of goods and services. Skilled labourers can create or innovate new technology that can improve the firm's TE (Fahmy-Abdullah, 2017). Essmui et al. (2013), Olatunji and Ibidunni (2013), and Ismail and Zainal Abidin (2015) show that training expenses is one of the factors that can reduce the firm's technical inefficiency. The training expenses incurred by the firm actually have a direct relationship with the increase of productivity (Dearden et al., 2006) and the training programs conducted should be in accordance with the needs of the firm. When training implemented is not in line with the needs of the employee, there will be wastage and no proper return is gained (Fahmy-Abdullah et al., 2018). Employee's skills are also associated with employee education level. Education is one of the key roles in identifying firm performance including output, profitability, and productivity (MPC, 2017). It plays a vital role in producing competitive human capital (Fahmy-Abdullah, 2017). 
Firm size also plays an important role in increasing the firm's efficiency. For the manufacturing sector, small and medium industries are defined as firms with sales of not less than RM300,000 and not exceeding RM50 million, while large firm size has sales revenue above RM50 million (SME Corp., 2013). Improved TE level is positively related to the increase in firm size (Batra \& Tan, 2003; Charoenrat et al. 2013; Fahmy-Abdullah et al., 2018). Besides, firms with more sophisticated machinery have higher levels of efficiency (Fahmy-Abdullah et al., 2019). Wage rates certainly play an important role as motivation and incentives for workers in a firm. A study by Elkin and Rosch (1989) found that interpersonal relationships in the organisation would become tense if there was an issue of wage rates and unfair promotion opportunities. In fact, the implementation of the Productivity-Based Wages System can benefit the firm as this system contributes to the enhancement of firm's competitiveness (National Productivity Corporation, 2010; FahmyAbdullah et al., 2017; Fahmy-Abdullah et al., 2018; Fahmy-Abdullah et al., 2019), which tends to increase wage rates.

In addition, information and communications technology (ICT) investments made by a firm can result in a positive impact. Emphasis on ICT investments can enhance the firm's efficiency (Ismail \& Zainal Abidin, 2015). Investment on data, physical input, incentives or subsidies and capital stocks to promote the development of innovation and the development of ICT strategic plans can enhance the firm's TE (Liew et al., 2012; Fahmy-Abdullah et al., 2017; Fahmy-Abdullah et al., 2018). Besides, investment in research and development also benefits a firm. Product innovation can influence the level of technical competence (Fahmy-Abdullah et al., 2017; Charoenrat 2013). In fact, modified and improved technology tools can reduce the cost of production (Olatunji \& Ibidunni, 2013). To the best of our knowledge, only Khalifah et al. (2015) and Khalifah and Jaafar (2017) who study TE of electrical and electronic manufacturing industry in Malaysia use data at the industry level. However, Khalifah et al. (2015) discuss the effect of indirect technology transfer on foreign direct investment (FDI). The results show that the overflow of FDI is not important and can increase the efficiency of engineering and industrial productivity. While Khalifah and Jaafar (2017) compared the factors of export intensity and trafficking trade to determine TE and the results showed that trade was a significant determinant factor and export intensity was not significant. Therefore, the latest research on the level of TE and the determinants of technical inefficiency of electrical and electronic manufacturing firms using firm-level data should be undertaken to increase the productivity of the industry in the future. 


\section{DATA AND METHODOLOGY}

The common approach used to estimate the maximum output level is the DEA model and the SFA model. The DEA model is a non-parametric approach that cannot make any assumptions regarding production functions. On the other hand, DEA is the best-performing manufacturing practice model based on input and output observations. However, the DEA model cannot identify the differences between inefficiencies and random errors (Coelli et al., 2005).

Farrell's (1957) measurement of the efficiency with the assumption of constant return to scale can be shown in Figure 1. The YY' isoquant line is the production boundary that reaches the level of efficiency. The form of an isoquant line represents the minimum set of inputs per unit of output required to produce a unit of production. The TE can be generated when the input combination occurs along the isoquant line while the input combination points are above or at the right of the linear lines such as point $\mathrm{P}$ cannot reach TE in production. While OR/OP ratio is TE level and production allocative efficiency at point $\mathrm{P}$ are represented by OS/OR ratio. The isocost CC' line shows the objective function to minimise costs. While overall efficiency (economic efficiency) is equal to $\mathrm{OR} / \mathrm{OP} \times \mathrm{OS} / \mathrm{OR}=\mathrm{OS} / \mathrm{OP}$.

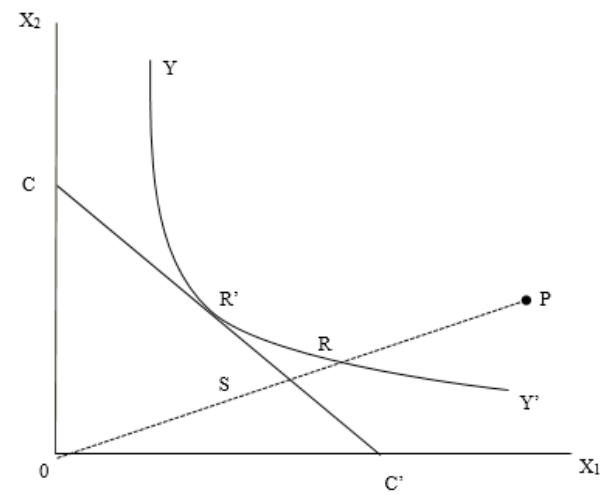

Figure 1. Illustraion of Farrell's (1957) efficiency measurement Source: Reillustrated by Murillo-Zamorano (2004)

The original SFA specification involves the production model devoted to crosssectional data having the conditions of error consisting of two components, first describing the random effects $\left(v_{i}\right)$ and both describing inefficiencies (ui) techniques. This original specification can be obtained from a comprehensive study previously conducted such as Forsund et al. (1980), Schmidt (1985), Bauer (1990), and Greene (2008). Kumbhakar (1990) and Battese and Coelli (1995) have proposed an easy model that can be used to measure inefficiencies. Following that, Battese 
and Coelli (1995) proposed an SFA model which contained the firm's assumed effects scattered as a normal trimmed random variable.

Model specification based on Battese and Coelli (1995) can be written as follows:

$$
\mathrm{Y}_{i}=\mathrm{X}_{i} \beta+\left(v_{i}-u_{i}\right)
$$

$\mathrm{Y}_{i}$ is the logarithm for production for firm $i$-th $(i=1,2, \ldots, \mathrm{N}), \mathrm{X}_{\mathrm{i}}$ is a vector $(\mathrm{k} \times 1)$ transformation of the input for firm $i$, and $\beta$ is a vector $(\mathrm{k} \times 1)$ unknown parameter. $u_{i}$ is a non-negative random variable that represents technical competence. $v_{i}$ is a random error and $z_{i}$ is $(1 \times p)$, an illustrative variable vector associated with the TE of the electrical and electronic industries. $\delta$ is a vector $(p \times 1)$, unknown parameter.

The coefficient in Equation 1 can be measured using the maximum likelihood estimation (MLE) method. Battese and Broca (1997) parameters are used to replace $\sigma_{v}^{2}$ and $\sigma_{u}{ }^{2}$ with $\sigma^{2}=\sigma_{v}{ }^{2}+\sigma_{u}{ }^{2}: \gamma=\sigma_{u}{ }^{2} /\left(\sigma_{v}{ }^{2}+\sigma_{u}{ }^{2}\right)$ (see Coelli and Battese, 1996) where $\gamma$ has a value between zero and one. If $H_{0}: \gamma=0$ is rejected, this proves that the deviation of the actual data from the boundary function is due to technical inefficiency. This means the null hypothesis about no technical inefficiency is rejected. To test the null hypothesis, a generalised likelihood-ratio (LR) L test, performed with the test statistic as follows:

$$
\lambda=-2\left\{\ln \left[L\left(H_{0}\right)\right]-\ln \left[L\left(H_{1}\right)\right]\right\}
$$

with $L\left(H_{0}\right)$ and $L\left(H_{1}\right)$ showing the likelihood function under null hypothesis and alternative hypothesis. If based on the hypothesis LR test $\left(H_{0}: \delta=0\right)$ is able to be rejected then the basic model without time factor will be used based on the model of Battese and Coelli (1995). The specification of these two models has been widely used through past studies to determine the value of TE once. The production TE for the $i$-th firm is defined as the actual output ratio with potential output as:

$\mathrm{TE}_{i}=E\left[\exp \left(-u_{i}\right)\right]$

Since $u_{i}$ is a non-negative variable, the efficiency is located between zero and one. A firm is technically efficient if the TE value is one and is inefficient if the value is zero. 


\section{Model Specification}

There are many estimation models adopted to study the relationship between input and output. The most popular estimation model is through Cobb-Douglas and Translog approach (Coelli et al., 2005) . Both approaches have been widely used by previous studies including Amornkitvikai and Harvie (2011) and FahmyAbdullah et al. (2017; 2018). However, past studies show that Translog's production function is better than Cobb-Douglas. Jarboui et al. (2013) asserted that the production function of Translog is a flexible function form because it does not require assumptions of the constant production elasticity (this represents output variation from input variation level) or elasticity of substitution between inputs (this represents the extent to which the input is able to replace the other as a result of relative change in input prices and at the same time maintains a constant output); the value varies from 0 (where it indicates that inputs are used in fixed and unchanged proportions) to infinity (in this case, the input is a perfect substitution and its consumption is very sensitive to relative price changes). Baten et al. (2009) state that the form of Translog's production function is better than Cobb-Douglas because it can demonstrate the real curve function rather than mere assumptions. Therefore, this study applied the Translog approach (Coelli et al., 2005).

SFA model based on Translog function:

$\ln Y_{i}=\beta 0+\sum_{j=1}^{n} \beta_{j} \ln X_{i j}+\frac{1}{2} \sum_{j}^{n} \sum_{l}^{n} \beta_{j l} \ln X_{i j} \ln X_{i j}+\left(v_{i}-u_{i}\right)$

where $\mathrm{Y}_{i}$ is output, $X$ is input, i.e., capital $\left(\mathrm{K}_{i}\right)$, labour $\left(\mathrm{L}_{i}\right)$ and intermediate input $\left(\mathrm{II}_{i}\right)$.

The first objective of this study is to measure the level of TE of the electrical and electronic manufacturing industry in Malaysia. The Frontier 4.1 program developed by Battese and Coelli (1995) will be used to analyse the data. While the second objective is to determine the factors inefficiencies in the electrical and electronic manufacturing industry in Malaysia by 2015 based on previous studies by FahmyAbdullah (2017), Essmui et al. (2013), Olatunji and Ibidunni (2013), Ismail and Zainal Abidin (2015), Batra and Tan (2003), Charoenrat et al. (2013), and FahmyAbdullah et al. (2018). The variables involved in the technical inefficiency of the SFA model are as follows:

$$
\begin{aligned}
& u_{i}=\delta_{0}+\delta_{1} \ln \mathrm{RKL}_{i}+\delta_{2} \ln \mathrm{RSEP}_{i}+\delta_{3} \ln \mathrm{RPT}_{i}+\delta_{4} \mathrm{DSME}_{i}+ \\
& \delta_{5} \ln \mathrm{ICT}_{i}+\delta_{6} \ln \mathrm{TRL}_{i}+\delta_{7} \ln \mathrm{W}_{i}+\delta_{8} \ln \mathrm{R} \mathrm{D}_{i}
\end{aligned}
$$


where $u_{i}$ is TE; $\mathrm{RKL}_{i}$ is the ratio of total capital and total worker in firm $i$; $\mathrm{RSEP}_{i}$ is the ratio of the worker in firm $i$ with the highest level of education at diploma and Sijil Tinggi Pelajaran malaysia (STPM) or equivalent; $\mathrm{RPT}_{i}$ is the ratio of worker in firm $i$ with high education; DSME is a dummy for firm $i(1=$ small firm, $0=$ other); $\mathrm{ICT}_{i}$ is the expenses on ICT for firm $i$; $\mathrm{TRL}_{i}$ is the total expenses of firm $i$ on training for workers; $\mathrm{W}_{i}$ is the wage rate for firm $i$; and R\&D is the expenses on research and development.

This study uses data at the firm level obtained from the Survey of Manufacturing Industries (SMI) conducted by the Department of Statistics (DOS) Malaysia through the latest Economic Census conducted in 2015. This study involved 10 sub-industries at the 3-digit level according to Malaysian Standard Industrial Classification (MSIC) 2008. Based on the original data obtained from the DOS, the screening process was once again carried out with some firms dropped due to lack of relevant information as incomplete (output or unquoted capital) and the number of employees was very small and does not meet the purpose of small and medium firms (less than 5 employees or 0 ) that will affect the sample analysis. Overall, 351 firms involved in this study are based on the latest 2015 Economic Census. All variables are in the real value of Ringgit Malaysia in 2010. The Frontier 4.1 program developed by Battese and Coelli (1995) is applied to analyse the TE level and the determinants of technical inefficiency in the electrical and electronics manufacturing industry in Malaysia.

\section{RESULTS AND DISCUSSION}

Based on data obtained from DOS, 351 electrical and electronic manufacturing firms in 2015 were selected in this study. Table 1 shows the descriptive statistics of variables in SFA estimation. This table shows that the average total output of the electricity and electronics manufacturing industry is RM529 million with a minimum sum of RM3 million to a maximum of RM16 billion. Meanwhile, capital is a major expense for the industry with average spending of RM96 million with a minimum and maximum amount of between RM57,000 to RM2.9 billion. In addition, the average number of workers employed was 936 people and the number of workers employed was from 10 to 15,676 workers. Meanwhile, the average value of intermediate input is RM430 million with a minimum amount of RM1.6 million to RM13.3 billion. The study also shows that the ratio between capital and labour ranges from RM840,000 to RM10 million with an average of RM126,000. The average ratio of employees with education qualification of diploma and STPM or equivalent 0.093 ranges from 0.000 to 0.732 . The average ratio of workers with the highest qualification includes an advanced degree or equivalent is 0.154 from 
0.000 to 0.815 . Meanwhile, small and medium-sized entreprise (SME)'s volume shows that $30 \%$ of the firms involved in the study are small and medium-sized firms. The firm has also spent an average of RM4.2 million for communication and information technology with minimum spending of RM0 and a maximum of RM750 million. Meanwhile, the average cost of employee training is RM235,000 with an expense of between RM0 to RM1.1 million. In addition, the firm's average wage rate is RM28,000, ranging from RM3,900 to RM148,000. Finally, firms also spend on research and development on an average of RM7 million with total expenditure ranging from RM0 to RM1.7 billion.

Table 1

Descriptive statistic

\begin{tabular}{llllll}
\hline Variable & Symbol & Min & Minimum & Maximum & Std. dev. \\
\hline Y & RM & 528,613 & 3,529 & $16,775,420$ & 1391847.099 \\
K & RM & 96,030 & 57 & $2,889,983$ & $251,000.045$ \\
L & Number & 936 & 10 & 15,676 & 1615.497 \\
II & RM & 435,132 & 1,637 & $13,268,578$ & 1164928.920 \\
RKL & Ratio & 125.716 & 0.840 & 10194.924 & 562.562 \\
RSEP & Ratio & 0.093 & 0.000 & 0.732 & 0.099 \\
RPT & Ratio & 0.154 & 0.000 & 0.815 & 0.154 \\
DSME & Dummy & 0.308 & 0 & 1 & 0.462 \\
ICT & RM & 4,218 & 0 & 750,087 & 46803.029 \\
TRL & RM & 235 & 0 & 11074 & 924.601 \\
W & RM & 28.812 & 3.924 & 148.758 & 16.497 \\
R\&D & RM & 7538 & 0 & 1703613 & 92676.010 \\
\hline
\end{tabular}

Notes: $\mathrm{Y}=$ ouput; $\mathrm{K}$ = capital; $\mathrm{L}=$ labour; $\mathrm{II}=$ intermediate input; $\mathrm{RKL}=$ ratio capital labour; $\mathrm{RSEP}=$ ratio of employees trained at diploma and Malaysian Higher School Certificate or equivalent; RPT = ratio of employees trained at a higher level including advanced degree or equivalent; DSME = dummy for small medium firms size; $\mathrm{ICT}=$ communications cost; $\mathrm{TRL}=$ employees training expenses; $\mathrm{W}=$ wage rate; $\mathrm{R} \& \mathrm{D}=$ research and development cost; RM = Ringgit Malaysia

Table 2 shows the parameters using the Translog production function approach. The results show that variables $\ln$ capital and (ln capital) ${ }^{2}$ show a significant relationship at the $1 \%$ and $10 \%$ significance level. These results show that these inputs meet the maximum requirements of the electrical and electronics manufacturing firms. Whereas $\ln$ workers, $\ln$ intermediate input, (ln workers) ${ }^{2}$, (ln intermediate input $)^{2}$, ln capital of the worker, ln capital of the intermediate input, and $\ln$ worker of the intermediate input have no significant relationship with the electrical and electronics manufacturing firms. This decision is associated with 
excess inputs resulting in inefficiency and the amount of output produced does not reach the maximum level (Law of Diminishing Return). Overall, the gamma parameter $(\gamma)$ obtained shows positive and significant values. This proves that technical inefficiency has had a significant impact on the level and change of production of electrical and electronic manufacturing industries in Malaysia. In addition, the sigma value of squared $\left(\sigma^{2}=\sigma_{\mathrm{v}}{ }^{2}+\sigma_{\mathrm{u}}{ }^{2}\right)$ is also significant, indicating that there are firms in the study not operating efficiently.

Table 2

Result of SFA

\begin{tabular}{|c|c|c|}
\hline Variable & Parameter & Coefficient of MLE \\
\hline Constant & $\beta_{0}$ & $\begin{array}{l}3.010 \\
(1.168)\end{array}$ \\
\hline In capital & $\beta_{1}$ & $\begin{array}{c}1.431 \\
(3.302)^{* * *}\end{array}$ \\
\hline ln worker & $\beta_{2}$ & $\begin{array}{c}0.209 \\
(0.357)\end{array}$ \\
\hline ln intermediate input & $\beta_{3}$ & $\begin{array}{c}0.163 \\
(0.316)\end{array}$ \\
\hline$(\ln \text { capital })^{2}$ & $\beta_{4}$ & $\begin{array}{c}-0.133 \\
(-1.771)^{*}\end{array}$ \\
\hline$(\ln \text { worker })^{2}$ & $\beta_{5}$ & $\begin{array}{c}0.137 \\
(1.096)\end{array}$ \\
\hline$(\ln \text { intermediate input })^{2}$ & $\beta_{6}$ & $\begin{array}{l}-0.015 \\
(-0.166)\end{array}$ \\
\hline $\begin{array}{l}(\text { ln capital)* } \\
\text { (ln worker) }\end{array}$ & $\beta_{7}$ & $\begin{array}{l}-0.041 \\
(0.571)\end{array}$ \\
\hline $\begin{array}{l}(\ln \text { capital })^{*} \\
(\text { ln intermediate input })\end{array}$ & $\beta_{8}$ & $\begin{array}{c}0.088 \\
(1.312)\end{array}$ \\
\hline $\begin{array}{l}(\text { ln worker) } \\
\text { (ln intermediate input) }\end{array}$ & $\beta_{9}$ & $\begin{array}{l}-0.132 \\
(-1.620)\end{array}$ \\
\hline Sigma-squared & $\sigma^{2}=\sigma_{\mathrm{v}}{ }^{2}+\sigma_{\mathrm{u}}{ }^{2}$ & $\begin{array}{c}1.407 \\
(13.210)^{* * *}\end{array}$ \\
\hline Gamma & $\gamma$ & $\begin{array}{c}0.999 \\
(4.093)^{* * *}\end{array}$ \\
\hline Log Likelihood & & -557.363 \\
\hline
\end{tabular}

Notes: ${ }^{* * *}$ and ${ }^{*}$ indicate significance at $1 \%$ and $10 \%$ and value in () is t statistic

Overall, the level of TE of the electrical and electronics manufacturing industry in Malaysia is at a high level in 2015. The results show that the average TE level 
is 0.836 as shown in Table 3. This shows that almost all firms operate at a high level to produce optimum output. Based on Annual GDP National Accounts Report (2016), electrical and electronics manufacturing firms remained as the key engine of growth for the manufacturing sector by registering $8.6 \%$ following an improvement in external demand (MPC, 2016).

Table 3

TE of electrical and electronic manufacturing industry in Malaysia

\begin{tabular}{lc}
\hline Firm & Average total TE \\
\hline $351^{*}$ & 0.836 \\
\hline
\end{tabular}

Notes: * data from the latest Economic Census 2015

Table 4 shows the results of the technical inefficiency variables in 2015. The negative sign obtained from the analysis shows that when there is an increase in the variables, there is a reduction in the technical inefficiency of the electrical and electronics manufacturing industry in Malaysia. On the other hand, if a positive sign is obtained, it indicates an increase in firm technical inefficiency.

Table 4

Determinants of inefficiency in industrial engineering and electrical manufacturing electronics in Malaysia

\begin{tabular}{lcc}
\hline Variable & Parameter & Coefficient \\
\hline Constant & $\delta_{0}$ & 1.869 \\
& & $(2.998)^{* * *}$ \\
ln capital-labour ratio & $\delta_{1}$ & 1.451 \\
& & $(8.000)^{* * *}$ \\
ln SEP ratio & $\delta_{2}$ & -0.061 \\
& & $(-0.441)$ \\
$\ln$ PT ratio & $\delta_{3}$ & -0.019 \\
& & $(-1.109)$ \\
Dummy for SME & $\delta_{4}$ & -0.527 \\
& & $(-2.115)^{* * *}$ \\
$\ln$ ICT expenses & $\delta_{5}$ & -0.011 \\
& & $(-0.179)$ \\
$\ln$ training expenses & $\delta_{6}$ & 0.040 \\
& & $(1.109)$ \\
$\ln$ wage rate & $\delta_{7}$ & 0.066 \\
$\ln$ research and development & & $(0.382)$ \\
\end{tabular}

Notes: ${ }^{* * *}$ indicates significant at $1 \%$ and value in ( ) is t statistic 
Based on the analysis performed, the firm's size shows a negative and significant relationship at $1 \%$ significant level; which means the technical inefficiency of firms can be reduced. When there is an increase in firm size by $1 \%$, the inefficient technique can be reduced by $0.5 \%$. Based on a survey, nearly $70 \%$ of the firms involved are big firms compared to only $30 \%$ of small and medium-sized firms. This proves that when there is an increase in firm size which can reduce the firm's inefficiency level. Based on GDP National Annual Account Report (2012), there has been a rise in growth for electronics and electronics manufacturing firms by $8.6 \%$ as a result of the external demand that has pushed the firms to increase the size of firms and thus increases the firm's efficiency. This finding also shows that firm's size is important and consistent with the findings of Batra and Tan (2003) and Fahmy-Abdullah et al. (2018).

Next, the capital-labour ratio was found to have a positive and significant relationship with increasing technical inefficiency of the electrical and electronics manufacturing firms. When there is an increase in the capital-labour ratio by $1 \%$, the technical inefficiency will increase by $1.4 \%$. Based on the Economic Census Report of 2015 (2016), the increase in the amount of capital received is greater than the increase in the number of employees. This situation may result in excessive capacity being utilised in the capital such as technology, but the skill level of worker will undoubtedly affect the firm's performance which ultimately reduces the overall efficiency of the firm (Fahmy-Abdullah et al., 2017; Fahmy Abdullah et al., 2019). There is also a probability that existing capital has been used for purposes other than raising employee productivity such as output production which results in increased technical inefficiency. Meanwhile, the result found that the determinant of the ratio of employees with secondary and higher education, ICT spending, training expenses, wage rates, and research and development had no significant relationship with the technical inefficiency.

\section{CONCLUSION}

The study aims to examine the level of efficiency and analyse the factors of inefficiency in electrical and electronics manufacturing industry in Malaysia. This study involved 351 firms where the data was obtained from DOS in 2015. Based on the results through the Translog production function, the efficiency of the electrical and electronic manufacturing industry in Malaysia is high with value efficiency of 0.84. Furthermore, the results show that size of firms play an important role in reducing the technical inefficiency of a firm as the findings of previous studies include Batra and Tan (2003) and Fahmy-Abdullah et al. (2018). Furthermore, the result shows that capital-labour ratio has positive relationship with technical 
inefficiency, which is in line with findings by Khalifah and Abu Talib (2008), Fahmy-Abdullah et al. (2017), and Fahmy Abdullah et al. (2019).

In terms of policy implications, this finding emphasises that the electrical and electronics manufacturing firms still need a lot of efforts to further improve the efficiency level, particularly emphasising the determinants that can improve the firm's efficiency. Some policy implications need to be taken into the 11 th Malaysia Plan (2015-2020) which places electrical and electronics manufacturing firms as one of the major industries contributing to the country's GDP. First, although the increase in firm size can increase the TE of electrical and electronics manufacturing firms, efforts to enhance the performance need to be continued using minimal inputs but may result in a maximum production or output amount and which a greater emphasis on economic performance scale (IRS - scale upward returns). Larger firms and more sophisticated engineering have higher TE (Fahmy-Abdullah et al., 2019). Second, capital utilisation needs to be in tandem with the skills of employees to adapt to new technologies. Workforce development programs and the provision of trained workforce in a number of areas including the handling of machinery, management, engineering, quality, design and cost management, and placing expert physicians in firms can enhance leadership skill momentum, management capabilities, and quality for human capital development. The use of excess capacity in the capital and at the same time the level of efficiency of the unskilled worker will have an impact on increased firmness in the firm's firmness (Khalifah $\&$ Abdul Talib, 2008). Third, firms need to be more aggressive by having technical cooperation with the industry internationally including enhancing investment and marketing missions specific to several countries and increasing interest among international industry players to work with local industries for overseas markets. This can contribute significantly to the growth and transformation of electrical and electronic manufacturing industries, especially to increase production capacity, job opportunities, trade, and technological capabilities. Domestic investment is a driving force for industrial growth that has combined the highest level of advanced technology and investment by international industrial players. This not only ensures technology transfer and innovation but also generates high-income jobs and economic opportunities to local firms.

\section{REFERENCES}

Amornkitvikai, Y., \& Harvie, C. (2011). Finance, ownership, executive remuneration, and technical efficiency: A stochastic frontier analysis (SFA) of Thai listed manufacturing enterprises. Australasian Accounting, Business and Finance Journal, 5(1), 35-55. 
Baten, M.A., Kamil, A.A., \& Haque, M.A. (2009). Modeling technical inefficiencies effects in a stochastic frontier production function for panel data. African Journal of Agricultural Research, 4(12), 1374-1382.

Batra, G., \& Tan, H. (2003). SME technical efficiency and its correlates: Cross-national evidence and policy implications. Washington, DC: World Bank.

Battese, G.E., \& Broca, S.S. (1997). Functional forms of stochastic frontier production functions and models for technical inefficiency effects: A comparative study for wheat farmers in Pakistan. Journal of Productivity Analysis, 8(4), 395-414.

Battese, G.E., \& Coelli, T.J. (1995). A model for technical inefficiency effects in a stochastic frontier production function for panel data. Empirical Economics, 20(2), 325332. https://doi.org/10.1007/bf01205442

Bauer, P.W. (1990). Decomposing TFP growth in the presence of cost inefficiency, nonconstant returns to scale, and technological progress. Journal of Productivity Analysis, 1(4), 287-299. https://doi.org/10.1007/bf00160047

Bertrand, J.M.A. (2013). Evolution of structural indicators: China and its regions 19812010. Journal of Chinese Economic and Foreign Trade Studies, 6(3), 100-118.

Charoenrat, T., Harvie, C., \& Amornkitvikai, Y. (2013). Thai manufacturing small and medium sized enterprise technical efficiency: Evidence from firm-level industrial census data. Journal of Asian Economics, 27, 42-56. https://doi.org/10.1016/j. asieco.2013.04.011

Coelli, T.J., \& Battese, G.E. (1996). Identification of factors which influence the technical inefficiency of Indian farmers. Australian Journal of Agricultural Economics, 40(2), 103-128. https://doi.org/10.1111/j.1467-8489.1996.tb00558.x

Coelli, T.J., Rao, D.S.P., O’Donnell, C.J., \& Battese, G.E. (2005). An introduction to efficiency and productivity analysis. London: Springer Science \& Business Media.

Cullinane, K., Wang, T.F., Song, D.W., \& Ji, P. (2006). The technical efficiency of container ports: Comparing data envelopment analysis and stochastic frontier analysis. Transportation Research Part A: Policy and Practice, 40(4), 354-374. https://doi.org/10.1016/j.tra.2005.07.003

Dearden, L., Reed, H., \& Van Reenen, J. (2006). The impact of training on productivity and wages: Evidence from British panel data. Oxford Bulletin of Economics and Statistics, 68(4), 397-421. https://doi.org/10.1111/j.1468-0084.2006.00170.x

Elkin, A.J., \& Rosch, P.J. (1989). Promoting mental health at the workplace: The prevention side of stress management. Occupational Medicine, 5(4), 739-754.

Essmui, H., Madeline, B., Faridah, S., \& Shamshubarida, R. (2013). Technical efficiency of manufacturing enterprises in Libya: A stochastic frontier analysis. International Journal of Management \& Information Technology, 5, 528-535. https://doi. org/10.24297/ijmit.v5i2.4445

Fahmy-Abdullah, M. (2017). Technical efficiency and total factor productivity in transport manufacturing firms in Malaysia. Doctoral dissertation, Universiti Kebangsaan Malaysia, Malaysia. https://doi.org/10.21315/aamj2017.22.1.3

Fahmy-Abdullah, M., Ismail, R., Sulaiman, N., \& Talib, B.A. (2017). Technical efficiency in transport manufacturing firms: Evidence from Malaysia. Asian Academy of Management Journal, 22(1), 57-77. 
Fahmy-Abdullah, M., \& Talib, B.A. (2018). Data envelopment analysis (DEA) approach in efficiency transport manufacturing industry in Malaysia. International Journal of Engineering \& Technology, 7(33), 339-343. https://doi.org/10.14419/ijet. v7i3.20.19270

Fahmy-Abdullah, M., Sieng, L.W., \& Isa, H.M. (2018). Technical efficiency in Malaysian textile manufacturing industry: A Stochastic Frontier Analysis (SFA) approach. International Journal of Economics and Management, 12(2), 407-419.

Fahmy-Abdullah, M., Sieng, L.W., \& Ridzuan, S. (2019). Data envelopment analysis (DEA) two stages in identify determinants factor of efficienct techniques for transport in manufacturing firms. Sains Malaysiana, 48(4), 901-908.

Farrell, M.J. (1957). The measurement of productive efficiency. Journal of the Royal Statistical Society Series A (General), 120(3), 253-290. https://doi. org/10.2307/2343100

Forsund, F.R., Lovell, C.K., \& Schmidt, P. (1980). A survey of frontier production functions and of their relationship to efficiency measurement. Journal of Econometrics, 13(1), 5-25. https://doi.org/10.1016/0304-4076(80)90040-8

Greene, W.H. (2008). The econometric approach to efficiency analysis. In H.O. Fried, C.A.K. Lovell, \& S.S. Schmidt (Eds)., The measurement of productive efficiency and productivity growth (pp. 92-250). London: Oxford Scholarship Online. https://doi.org/10.1093/acprof:oso/9780195183528.003.0002

Ismail, R., Sulaiman, N., \& Fahmy-Abdullah, M. (2017). Globalization and total factor productivity growth in the Malaysian construction sector. Global Economy and Finance Journal, 10(2), 24-40. https://doi.org/10.21102/gefj.2017.09.102.02

Ismail, R., \& Zainal Abidin, S. (2015). Pekerja efektif dan kecekapan teknik firma pembuatan di Malaysia. Proceeding of the 2nd CHREST International Conference 2015: Transforming Human Capital for Global Competitiveness, 309-322.

Jajri, I., \& Ismail, R. (2014). Total factor productivity and output growth of the services sector in Malaysia. Research Journal of Applied Sciences, 9(12), 936-940.

Jabatan Perangkaan Malaysia. (2017). National accounts gross domestic product (GDP) 2016. Putrajaya: Jabatan Perangkaan Malaysia.

Jabatan Perangkaan Malaysia. (2018a). External trade statistics 2017. Putrajaya: Jabatan Perangkaan Malaysia.

Jabatan Perangkaan Malaysia. (2018b). National income account 2017. Putrajaya: Jabatan Perangkaan Malaysia.

Jarboui, S., Forget, P., \& Boujelben, Y. (2015). Efficiency evaluation in public road transport: A Stochastic Frontier Analysis. Transport, 30(1), 1-14. https://doi.org/ 10.3846/16484142.2013.785019

Katz, J.M. (1969). Production functions, foreign investment and growth: A study based on the Argentine manufacturing sector, 1946-1961. Amsterdam: North-Holland.

Khalifah, N.A., \& Abdul Talib, B. (2008). Are foreign multinationals more efficient? A stochastic production frontier analysis of Malaysia's automobile industry. International Journal of Management Studies, 15, 91-113.

Khalifah, N.A., Mohd Salleh, S., \& Adam, R. (2015). FDI productivity spillovers and the technology gap in Malaysia's electrical and electronic industries. Asian-Pacific Economic Literature, 29(1), 142-160. https://doi.org/10.1111/apel.12094 
Khalifah, N.A., \& Jaafar, Z. (2017). Technical efficiency of establishments in Malaysia's electrical and electronics industries: Exporting or vertical trade? Jurnal Ekonomi Malaysia, 51(1), 15-32.

Kumbhakar, S.C. (1990). Production frontiers, panel data, and time-varying technical inefficiency. Journal of Econometrics, 46(1), 201-211. https://doi. org/10.1016/0304-4076(90)90055-x

Le, V., \& Harvie, C. (2010). Firm performance in Vietnam: Evidence from manufacturing small and medium enterprises. Working paper 04-10, Department of Economics, University of Wollongong, Australia.

Liew, C.S., Zulridah, M.N., \& Tee, B.A. (2012). Kesan ICT terhadap produktiviti pekerja dalam sektor perkhidmatan terpilih di Malaysia. Jurnal Ekonomi Malaysia, 46(2), 115-126. https://doi.org/10.17576/jem-2016-5002-06

Mahadevan, R. (2002a). Assessing the output and productivity growth of Malaysia's manufacturing sector. Journal of Asian Economics, 12(4), 587-597. https://doi. org/10.1016/s1049-0078(01)00104-x

Mahadevan, R. (2002b). A DEA approach to understanding the productivity growth of Malaysia's manufacturing industries. Asia Pacific Journal of Management, 19(4), 587-600.

Mahadevan, R. (2002c). Is there a real TFP growth measure for Malaysia's manufacturing industries? ASEAN Economic Bulletin, 178-190. https://doi.org/10.1355/ae19-2e

Malaysia Productivity Corporation (MPC). (2015). Malaysia Productivity Corporation report 2014 and 2015. Petaling Jaya: MPC.

MPC. (2016). Malaysia Productivity Corporation report 2015 and 2016. Petaling Jaya: MPC.

MPC. (2017). Malaysia Productivity Corporation report 2016 and 2017. Petaling Jaya: MPC.

Md Isa, R. (2005). Total factor productivity growth, efficiency and technological progress of the Malaysian manufacturing sector. Doctoral dissertation, Universiti Putra Malaysia, Malaysia.

Ministry of International Trade and Industry (MITI). (2016). Malaysia International Trade and Industry report 2015. Kuala Lumpur: MITI.

Murillo-Zamorano, L.R. (2004). Economic efficiency and frontier techniques. Journal of Economic Surveys, 18(1), 33-77. https://doi.org/10.1111/j.14676419.2004.00215.x

National Productivity Corporation. (2010). Productivity linked wage system in collective agreement. Kuala Lumpur: National Productivity Corporation.

Nelson, R.R., \& Phelps, E.S. (1966). Investment in humans, technological diffusion, and economic growth. The American Economic Review, 56(1/2), 69-75.

Olatunji, A.J., \& Ibidunni, A.A. (2013). Characteristics and efficiency of manufacturing firms in Nigeria. European Journal of Social Sciences, 37(1), 121-138.

Porcelli, F. (2009). Measurement of technical efficiency: A brief survey on parametric and non-parametric techniques. Warwick: University of Warwick.

Schmidt, P. (1985). Frontier production functions. Econometric Reviews, 4(2), 289-328. 
Siang, L.C., Noor, Z.M., \& Ann, T.B. (2012). Kesan ICT terhadap produktiviti pekerja dalam sektor perkhidmatan terpilih di Malaysia. Jurnal Ekonomi Malaysia, 46(2), 115-126. https://doi.org/10.17576/jem-2016-5002-06

SME Corp. (2013). Guidelines for new SME definition. Kuala Lumpur: SME Corp.

Solow, R.M. (1956). A contribution to the theory of economic growth. The Quarterly Journal of Economics, 70(1), 65-94.

Stevens, P.A., \& Kneller, R. (2003). Absorptive capacity and frontier technology: Evidence from OECD manufacturing industries. Royal Economic Society Annual Conference 2003, no. 193, Royal Economic Society.

Sulaiman, N. (2012). An input-output analysis of the total factor productivity growth of the Malaysian manufacturing sector, 1983-2005. Jurnal Ekonomi Malaysia, 46(1), 147-155.

Sulaiman, N., \& Rashid, Z.A. (2013). Decomposition of productivity growth of the Malaysian manufacturing sector, 1983-2005. Jurnal Ekonomi Malaysia, 47(1), 65-74.

Sun, X., Lv, X., \& Li, L. (2015). Sufficient and comprehensive measurement of automobile manufacturing industry performance applying bi-objective super-efficiency DEA. Proceedings of the 2015 International conference on Applied Science and Engineering Innovation. https://doi.org/10.2991/asei-15.2015.412

Tingley, D., Pascoe, S., \& Coglan, L. (2005). Factors affecting technical efficiency in fisheries: Stochastic production frontier versus data envelopment analysis approaches. Fisheries Research, 73(3), 363-376. https://doi.org/10.1016/j. fishres.2005.01.008 